\title{
Comparison between Normal and PSE Porcine Muscle in the Extractability of Myosin $B$ and in the Rheological Properties of Those Sausages
}

\author{
Hyung Kee Park, Tatsumi Ito and Toshiyuki Fukazawa \\ Faculty of Agriculture, Kyushu University, Fukuoka-shi 812 \\ (Received November 11, 1974)
}

\begin{abstract}
The rheological properties of sausages made from normal, and pale, soft and exudative (PSE) muscles and the extractability of myosin B of the both muscles were studied. The effects of pyrophosphate on the rheological properties of the sausages and the extractability of myosin B were also studied. The rheological properties - hardness, cohesiveness, springiness and chewiness, of sausages made from PSE muscles were much less than those of normal muscle. The extractability of myosin B of PSE muscle was also much less than that of normal. The rheological properties of sausages made from normal muscle were markedly improved by the addition of pyrophosphate, whereas in the case of PSE muscle pyrophosphate did not improve significantly the rheological properties. Pyrophosphate also increased the extractability of myosin B of normal muscle. However, the extractability of myosin B of PSE muscle did not increase significantly by the addition of pyrophosphate. The interrelationship between the extractability of myosin B of PSE muscle and its acceptability for sausage manufacturing was discussed.
\end{abstract}

It has been established that extremely rapid glycolytic rates, with low $\mathrm{pH}$ values and rapid loss of high energy phosphates were associated with the development of pale, soft and exudative (PSE) muscle $^{1 \sim 9)}$. Recently, muscle metabolism underlying the production of PSE muscle was demonstrated precisely by Bickhard ${ }^{10)}$ and Намm and Porthast ${ }^{11}$. In Japan, Fujimaki et al. ${ }^{12)}$ reported that $\mathrm{pH}$ values, water-holding capacity, myoglobin content and ATPase activity of myosin B of PSE-like porcine muscle were lower than those of normal muscle. Although the appearance of PSE muscle in Japan is literally pale, soft and exudative as well, it remains uncertain whether or not PSE muscle in Japan is the same as those of Europe and United States of America up to date.

It has also been found that meat products made from PSE muscle were much inferior in quality to those of normal muscle ${ }^{13-21}$. However, biochemical properties of myofibrillar proteins of PSE muscle in relation to its acceptability for meat processing have not been satisfactorily elucidated, although the acceptability of muscle for meat processing has been supposedly influenced by the biochemical properties of myofibrillar proteins of the muscle ${ }^{22}$.

In the present study, the rheological properties of sausage made from porcine muscle and the extractability of myosin B were studied, and the interrelationship between the extractability of myosin B of PSE muscle and its acceptability for sausage manufacturing was discussed.

\section{Materials and Methods}

Materials: 


\section{Comparison between Normal and PSE Muscle}

Normal and PSE muscles were selected from porcine muscles (about six months old) hung for $3-4 \mathrm{hrs}$ at room temperature and then stored in a cold room $\left(4-6^{\circ} \mathrm{C}\right)$ for $20-21 \mathrm{hrs}$ after slaughter. Selection of normal and PSE muscles was made by organoleptic assessment and the $\mathrm{pH}$ values proposed by BRisker2s). This study was made in September, October and December.

Determination of $\mathrm{pH}$ :

The $\mathrm{pH}$ of the muscle investigated was determined as follows: after the addition of $10 \mathrm{~m} l$ of distilled water to $5 \mathrm{~g}$ of minced muscle, the mixture was homogenized with a Waring Blender for $3 \mathrm{~min}$. The $\mathrm{pH}$ of the resulting muscle homogenate was determined at $20^{\circ} \mathrm{C}$ with a HitachiHoriba $\mathrm{pH}$ meter $\mathrm{F}-7$.

Extractability of myosin B:

Myosin B was extracted from $M$. longissimus dorsi of normal and PSE porcine muscles with 5 vol of Weber-Edsall solution at $0^{\circ} \mathrm{C}$ for $24 \mathrm{hrs}$ with gentle stirring, followed by centrifugation $(900 \mathrm{~g}$, $15 \mathrm{~min}$ ). The supernatant was diluted to $\mu=0.1$ with cold distilled water. The resulting precipitate was collected by centrifugation and was then dissolved in $0.6 \mathrm{M} \mathrm{KCl}$. The protein concentration of the solution was estimated by micro-Kjeldahl method. The effect of pyrophosphate on the extractability of myosin B from normal and PSE muscle were examined as follows: sodium pyrophosphate $(0.3 \mathrm{~g} / 100 \mathrm{~g}$ minced muscle) was added to Weber-Edsall solution prior to extraction. The extraction and determination of myosin $\mathrm{B}$ was conducted as described above.

Preperation of experimental sausage:

After curing normal and PSE muscles with $3 \% \mathrm{NaCl}$ at $4^{\circ} \mathrm{C}$ for $24 \mathrm{hrs}$, the cured meats were ground and homogenized with added ice cold water ( $7 \%$ to meat weight), and then stuffed into polyvinylidene chloride casing $\left(4.45 \mathrm{~cm}\right.$ in diameter). Cooking was done at $75^{\circ} \mathrm{C}$ for $60 \mathrm{~min}$. In examining the effect of pyrophosphate on sausage manufacturing, sodium pyrophosphate $(0.3 \mathrm{~g} / 100 \mathrm{~g}$ minced muscle) dissolved in ice cold water was added to minced muscle [just prior to homogenization.

Determination of rheological parameters:

The determination of the hardness, cohesiveness, springiness and chewiness of sausages made from normal and PSE muscles was made with a texturometer (Zenken Co. Ltd.). Hardness was estimated by the height of response of the detector representing the force required for the plunger of the texturometer to penetrate a mass $(1.27 \mathrm{~cm}$ in thick, $4.45 \mathrm{~cm}$ in diameter $)$ of sausage. Cohesiveness was estimated by comparing the areas of first chewing and second chewing on the chart, where first chewing represented the force and delayed time when the plunger bit a mass of sausage at first time, and second chewing represented those of second. Springiness was calculated by subtracting $\mathrm{B}$ from $\mathrm{C}$, where $\mathrm{B}$ represents the distance between the point of contact of first chewing and that of second, and $\mathrm{C}$ represents the distance in the case of the substance which has no springiness like clay. Chewiness was calculated by multiplying hardness and cohesiveness and springiness.

\section{Results and Discussion}

As well known, PSE muscle is inadequate for meat processing. This is the most important fault of PSE muscle. So, in order to elucidate the acceptability of PSE muscle for sausage manufacturing, some rheological properties of the sausage made from PSE muscle were determined by using a texturometer. Plate 1 shows the appearance of the sausages made from normal and PSE muscles before and after determining the textural properties. In the case of the sausages made from normal muscle, the texture was dense, and hence it was hard to deform even when the 
plunger of the texturometer bit a mass of the sausages (Plates 1-a and 1-b). On the other hand, in the case of the sausages made from PSE muscle, the texture was coarse, and they easily crum. bled (Plates 1-c and 1-d).

In utilization of PSE muscle for sausage manufacturing, several results have been reported by some workers. LUDVIGSEN ${ }^{24)}$ found that the watery meat which had somewhat lower ultimate $\mathrm{pH}$, bound $21-30 \%$ less water than normal meat, and the cooked sausages had considerably lower quality than corresponding sausages from normal meat. Recently, MERKEL ${ }^{21)}$ also found that bologna sausage made with PSE muscle had significantly greater losses during processing than normal muscle. Bologna containing PSE muscle was significantly paler in color than that from normal muscle. A tenderometer reading taken on the processed bologna stick indicated that the PSE product was tenderer than normal. Moreover, bologna containing high portions of PSE muscle (80\% or 100\%) were to mushy. However, it remains obscure how degenerated the PSE muscle used for bologna sausage manufacturing, because $\mathrm{pH}$ of the PSE muscle was unwritten.

Table 1 presents the rheological properties of the sausages made from normal and PSE muscles. The hardness, cohesiveness, springiness and chewiness of the sausages made from PSE muscle were much less than normal. We can not accurately evaluate the significance of the values in this table, since the standard values of these parameters for sausages have not been established. However, it is clear that these values show relative acceptability of sausages from normal and PSE muscles. In this respect, the results in Table 1 indicate that the sausage made from PSE muscle is much inferior in quality to that of normal muscle. In addition, the rheological parameters of the sausages were related to $\mathrm{pH}$ of the muscle used for sausage manufacturing, i.e., the lower the $\mathrm{pH}$ the lower the rheological properties. Thus, it seems that $\mathrm{pH}$ values of muscle is a very im. portant factor for sausage manufacturing.

Plate 2 shows the appearance of the sausages made from normal and PSE muscles with or without pyrophosphate. As in the case of plate 1, upper row shows the appearance of the sausages before determining textural properties and lower row those after the determination. In the case of the sausage made from normal muscle with pyrophosphate, the texture was dense, and hence it was very hard to deform when the plunger bit a mass of the sausage (Plate 2-a), whereas in the case of the sausage made from PSE muscle with pyrophosphate the texture was coarse and it easily crumbled too (Plate 2-c). Table 2 presents the rheological properties of the sausages made

Table 1. Texturometer evaluation of sausages made from normal and PSE muscles

\begin{tabular}{ccccccc}
\hline $\begin{array}{c}\text { Trial } \\
\text { No }\end{array}$ & $\begin{array}{c}\text { Visual } \\
\text { division }\end{array}$ & $\mathrm{pH}$ & Hardness & Cohesiveness & Springiness & Chewiness \\
\hline 1 & Normal & 5.78 & 13.6 & 0.65 & 6.5 & 57.54 \\
2 & Normal & 5.69 & 12.0 & 0.66 & 5.5 & 43.54 \\
3 & Normal & 5.51 & 10.6 & 0.60 & 5.5 & 34.98 \\
4 & Normal & 5.47 & 9.8 & 0.56 & 5.5 & 30.40 \\
5 & Normal & 5.46 & 8.0 & 0.46 & 4.5 & 16.60 \\
6 & PSE & 5.44 & 6.4 & 0.44 & 3.5 & 9.86 \\
7 & PSE & 5.42 & 5.2 & 0.46 & 3.5 & 8.37 \\
8 & PSE & 5.38 & 4.8 & 0.40 & 3.5 & 6.72 \\
9 & PSE & 5.32 & 3.7 & 0.38 & 3.5 & 4.90 \\
10 & PSE & 5.26 & 3.5 & 0.39 & 2.5 & 3.50 \\
\hline
\end{tabular}


(a)

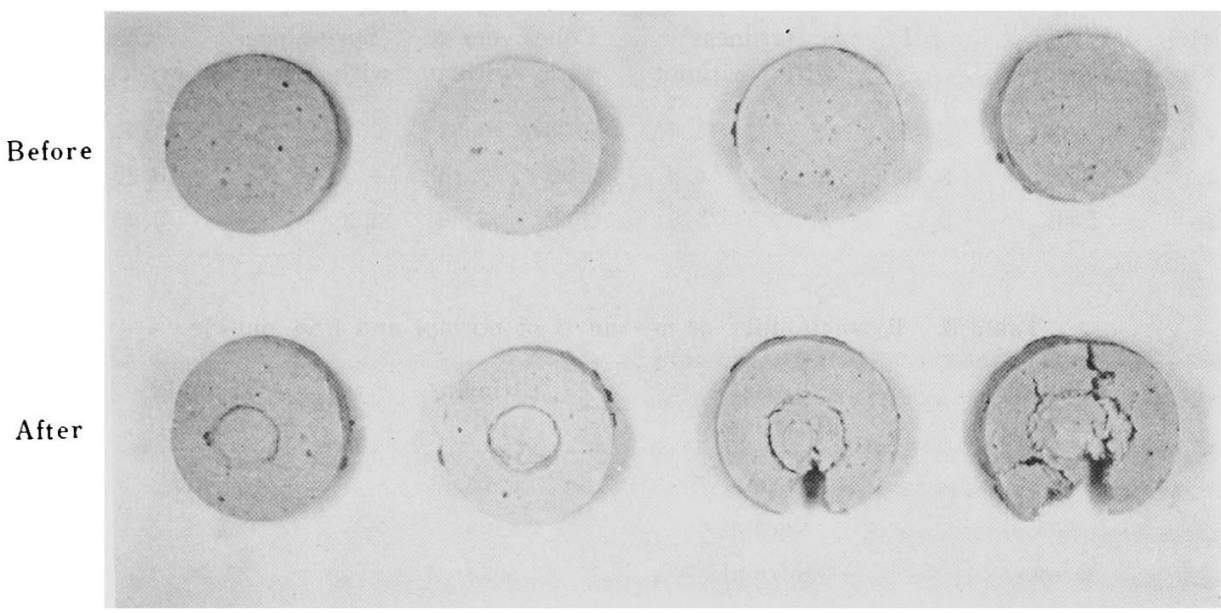

Plate 1. The appearance of sausage made from normal and PSE porcine muscle before and after determining the textural properties with a texturometer (a), sausage made

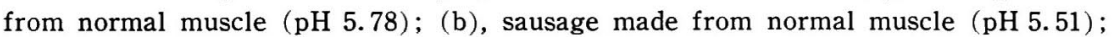

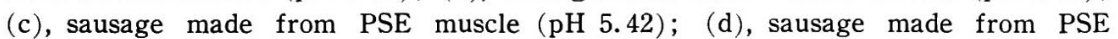
muscle ( $\mathrm{pH} 5.38)$

(a)

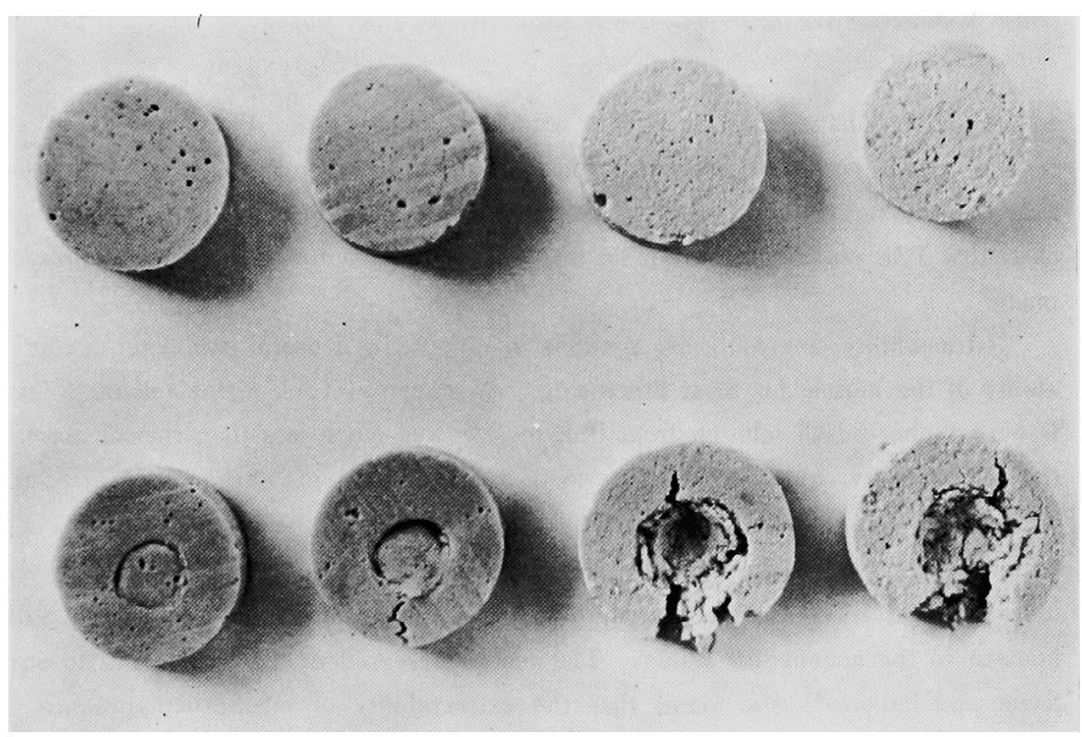

Plate 2. The appearance of sausage made from normal and PSE porcine muscle with or without pyrophosphate.

(a), sausage made from normal muscle ( $\mathrm{pH} 5.67$ ) with pyrophosphate; (b), sausage made from normal muscle ( $\mathrm{pH} 5.67$ ) without pyrophosphate; (c), sausage made from PSE muscle ( $\mathrm{pH} 5.27$ ) with pyrophosphate; (d), sausage made from PSE muscle ( $\mathrm{pH}$ 5.27) without pyrophosphate 
Park, Ito and Fukazawa

Table 2. Texturometer evaluation of sausage made from normal and PSE muscle with or without pyrophosphate

\begin{tabular}{|c|c|c|c|c|c|c|c|c|c|c|}
\hline \multirow{2}{*}{$\begin{array}{l}\text { Trial } \\
\text { No }\end{array}$} & \multirow{2}{*}{$\begin{array}{l}\text { Visual } \\
\text { division }\end{array}$} & \multirow[t]{2}{*}{$\mathrm{pH}$} & \multicolumn{2}{|c|}{ Hardness } & \multicolumn{2}{|c|}{ Cohesiveness } & \multicolumn{2}{|c|}{ Springiness } & \multicolumn{2}{|c|}{ Chewiness } \\
\hline & & & with & without & with & without & with & without & with & without \\
\hline 1 & Normal & 5.67 & 15.70 & 11.45 & 0.78 & 0.52 & 7.75 & 6.5 & 94.91 & 38.70 \\
\hline 2 & PSE & 5.40 & 6.1 & 4.8 & 0.50 & 0.46 & 4.5 & 3.5 & 13.73 & 7.73 \\
\hline 3 & PSE & 5.27 & 5.7 & 5.8 & 0.48 & 0.48 & 3.2 & 3.0 & 8.76 & 8.35 \\
\hline
\end{tabular}

Table 3. Extractability of myosin B of normal and PSE muscle

\begin{tabular}{cccc}
\hline $\begin{array}{c}\text { Sample } \\
\text { No }\end{array}$ & $\begin{array}{c}\text { Visual } \\
\text { Division }\end{array}$ & $\begin{array}{c}\text { Ultimate } \\
\mathrm{pH}\end{array}$ & $\begin{array}{c}\text { Myosin } \mathbf{B}^{\mathrm{a}} \\
(\%)\end{array}$ \\
\hline 2 & $\begin{array}{c}\text { Normal } \\
\text { Normal }\end{array}$ & 5.78 & 34.07 \\
3 & Normal & 5.69 & 33.70 \\
4 & Normal & 5.64 & 34.00 \\
5 & Normal & 5.51 & 25.50 \\
6 & PSE & 5.44 & 22.40 \\
7 & PSE & 5.42 & 13.76 \\
8 & PSE & 5.38 & 4.47 \\
9 & PSE & 5.34 & 6.25 \\
10 & PSE & 5.32 & 4.97 \\
\hline
\end{tabular}

a) Extractability of myosin $B$ was expressed as a percentage of the total protein in muscle.

from normal and PSE muscles with or without pyrophosphate. Pyrophosphate greatly improves the textural properties of the sausage made from normal muscle, whereas it does not improve signifi. cantly the textural properties of the sausages made from PSE muscles. From these results, it is clear that PSE muscle is inadequate for sausage manufacturing even in the presence of pyrophosphate.

Extractability of myofibrillar proteins is supposedly a useful parameter to elucidate the acceptability of the muscle for meat processing. As shown in Table 3 , the amount of extractable myosin $B$ with Weber-Edsall solution from PSE muscle was much less than that of normal one. Besides, the extractability of myosin $\mathrm{B}$ seems to be related to the $\mathrm{pH}$ of the muscle, i. e., the lower the $\mathrm{pH}$ the less the extractability. WISMer-Pedersen ${ }^{25)}$ found that the high weight loss of meat which denoted a low water-binding capacity, was connected with a decreased solubility of the muscle proteins in $0.6 \mathrm{M} \mathrm{KCl}$. He considered the decreased solubility to be the result of a denaturation phenomena in the actomyosin system. The result presented in Table 3 seems to support this idea. SAYRE and BRISKEY ${ }^{2 B}$ also found that the extractability of myofibrillar proteins in PSE muscle with 1.1 M KI solution was much less than that of normal muscle. From titration studies BENDALL and Wismer-PEDERSEN 27), however, found that washed fibrils obtained from watery pork have a lower water retention at low ionic strength, and much lower extractability at high ionic strength, than the fibrils from normal pork. These changes were accompanied by a gain of protein by the washed watery fibrils, and this protein originated from soluble sarcoplasmic proteins. Therefore, they interpreted that the watery conditions of pork meat were not due to aggregation or denaturation in 


\section{Comparison between Normal and PSE Muscle}

Table 4. Effect of pyrophosphate on the extractability of myosin B from normal and PSE muscle

\begin{tabular}{cccc}
\hline $\begin{array}{c}\text { Visual } \\
\text { Division }\end{array}$ & $\mathrm{pH}$ & with pyrophosphate & Extractability \\
without pyrophosphate \\
\hline Normal & 5.67 & 37.95 & 31.85 \\
PSE & 5.40 & 14.86 & 12.47 \\
PSE & 5.27 & 13.17 & 10.67 \\
\hline
\end{tabular}

the usual sense, but rather due to adsorption of denatured sarcoplasmic proteins onto the surface of the fibrils and myofilaments. At any rate, these results suggest that the deficiency in waterbinding capacity of PSE muscle is closely related to the scantiness in extractability of myofibrillar proteins of PSE muscle. It is well known that the binding properties of sausage is related to the biochemical properties of myosin and/or actomyosin in muscle ${ }^{283}$. The extractability of myofibrillar proteins is supposedly concerned with water-holding capacity and binding property of meat products $^{29}$. Thus, the rheological properties of sausages made from PSE muscle might reflect the biochemical properties of myofibrillar proteins of PSE muscle. This consideration seems to be consistent with the results presented in Tables 1 and 3. This is also true in the case of normal muscle as well. Therefore, it seems that actomyosin system in PSE muscle might be denatured and the extent of the denaturation of actomyosin system might be related to the $\mathrm{pH}$ of the muscle.

Table 4 presents the effect of pyrophosphate on the extractability of myosin B from normal and PSE muscles. The extent of the increase in the extractability of myosin B from normal muscle was much more than PSE, although there was no significant difference in the increase ratio in the extractability between normal and PSE muscle. It is also known that binding property and water-holding capacity of meat are improved by the addition of phosphates such as pyrophosphate and tripolyphosphate ${ }^{30}$. However, in the present study pyrophosphate did not improve significantly the rheological properties of the sausages made from PSE muscle (Table 2). Therefore, it seems that acceptability of PSE muscle for sausage manufacturing is not improved by the addition of pyrophosphate, although a little increase in the extractability was found (Table 4).

The biochemical properties of myofibrillar proteins of PSE muscle is now under investigation.

We are greatly indebted to Drs. Y. KodA and 1. HAYAKAWA of Kyushu University for their guidance in texturometry. Thanks are also due to Nippon Shokuhin Co. Ltd. for their supply pork meats. This research was supported by a grant from the Ministry of Education of Japan.

\section{References}

1) Briskey, E. J., R.W. Bray, W. G. Hoekstra, P. H. Phillips, and R. H. Grummer, J Anim Sci 18: 146-152. 1959.

2) Briskey, E. J., and J. Wismer-Pedersen, J Food Sci 26: 297-305. 1961.

3) Sayre, R. N., E. J. Briskey, and W. G. Hoekstra, Proc Soc Exptl Biol Med 112: 223-225.1963.

4) SAYER, R. N., E. J. Briskey, and W. G. Hoekstra, J Anim Sci 22: 1012-1020. 1963.

5) Bendall, J.R., O. Hallund, and J. Wismer-Pederson, J Food Sci 28: 156-162. 1963.

6) Kastenschmidt, L. L., W. G. Hoekstra, and E. J. Briskey, Nature 212: 288-289. 1966.

7) Kastenschmidt, L. L., W. G. Hoekstra, and E. J. Briskey, J Food Sci 33: 151-158. 1968.

8) Lister, D., R. A. Sair, J.A. Will, G. R. Schmdt, R. G. Cassens, W. G. Hoerstra, and E. J. 


\section{Park, Ito and Fukazawa}

Briskey, Am J Physiol 218: 102-107. 1970.

9) Sair, R, A., D. Lister, W. G. Moody, R. G. Cassens, W. G. Hoekstra, and E. J. Briskey, Am J Physiol 128: 108-114. 1970.

10) Bickhardt, K., Proceedings of the 2nd International Symposium on Condition and Meat Quality 36-42. Center for Agricultural Publishing and Documentation. Wageningen. 1971.

11) HaMm, R., and R. Potthast, Fleischwirtschaft 52: 206-208. 1972.

12) Fujimaki, M., N. Arakawa, and A. Suzuki, Jap J Zootech Sci 36: 474-477. 1965.

13) Wismer-Pedersen, J., Food Res 25: 789-798. 1960.

14) Wismer-Pedersen, J., Food Res 25: 799-801. 1960.

15) Meyer, J. A., E. J. Briskey, W. G. Hoekstra, and R. G. Wecken, Food Technol 17: 485-489. 1963.

16) Karmas, E., and J.E. Thompson, Food Technol 18: 248-251. 1964.

17) Sayre, R. N., B. Kiernat, and E. J. Briskey, J Food Sci 29: 175-181. 1964.

18) Kemp, J. D., D. L. Gammon, W. G. Moody, and J. A. Jacobs, J Anim Sci 27: 366-369. 1968.

19) Moerman, P.C., and B. Krol, Recent Points of View on the Condition and Meat Quality of Pigs for slaughter 237-247. Research Institute for Animal Husbandry. Zeist. 1969.

20) Fox, J. D., W. G. Moody, J.D. Kemp, and W. Henning, J Anim Sci 31: 323-326. 1970.

21) Merkel, R. A., Proceedings of the 2nd International Symposium on Condition and Meat Quality of Pigs. 261-270. Centre for Agricultural Publishing and Documentation. Wageningen. 1971.

22) Wismer-Pedersen, J., Recent Points of View on the Condition and Meat Quality of Pigs for Slaughter 53-84. Research Institute for Animal Husbandry. Zeist. 1969.

23) Briskey, E. J., Adv Food Res 13: 89-178. 1964.

24) LUdvigsen, J., Unders $\phi$ gelser over den sakalde "muskeldegeneration" hos svin I. 272. beretn. fra fors $\phi$ gslaboratoriet, Kobenhavn. 1954. (Cited from Recent Points of View on the Condition and Meat Quality of Pigs for Slaughter. Research Institute for Animal Husbandry, Zeist.1969.)

25) Wismer-Pedersen, J., Food Res 24: 711-726. 1959.

26) Sayre, R. N., and E. J. Briskey, J Food Sci 28: 675-679. 1963.

27) Bendall, J.R., and J. Wismer-Pedersen, J Food Sci 27: 144-159. 1961.

28) Fukazawa, T., Y. Hashmoto, and T. Yasui, J Food Sci 27: 541-549. 1961.

29) Hamm, R., Adv Food Res 10: 355-463. Academic Press Inc., New York. 1960.

30) Fukazawa, T., Y. Hashimoto, and T. Yasui, J Food Sci 26: 550-555. 1961.

\section{正常豚肉および PSE 豚肉のミオシンB の抽出性ならびに それらのソーセージのレオロジー的性質の比較}

\section{朴亭基・伊藤肇躬・深沢利行 九州大学農学部，福岡市 812}

\begin{abstract}
正常豚肉拈よび PSE 䀠肉加らのオシンBの抽出性 とこれらの成肉で製造したンーセージのレオロジー的性 質について検副した，PSE豚肉名らのミオシンBの抽 出性は正常豚闪からのミオシンBの抽出性に比して著し く低く，かつまた，その抽出性は豚肉の $\mathrm{pH}$ に依存する こ己が明らかれなった. PSE 豚肉でっくったンーセー ジの硬さ，凝集性，弾力性および目嘫性はいずれも正常
\end{abstract}

膯肉でつくったッーセージのものよりも著しく劣ってい ※. ピロリン酸塩の添加は正常豚肉からのミオシン $\mathrm{B} の$ 抽出性およびッーセージのレオロジ一的性質苦著しく高 めるが，PSE豚に対してはそれはどの効果は認められ なかった。 これらの知見にもとづき，ンーセージのレオ ロジー的性質とミオンンBの抽出性との関倸について考 察した。 